\title{
Toxicological analysis of water mixtures of organic micropollutants subjected to UV irradiation
}

\author{
Edyta Kudlek $^{1, *}$ \\ ${ }^{1}$ Silesian University of Technology, Faculty of Energy and Environmental Engineering, Konarskiego \\ 18a, 44-100 Gliwice, Poland
}

\begin{abstract}
The paper presents the toxicological analysis of water solutions of micropollutants from different groups i.e. industrial additives, pharmaceutical compounds, hormones, UV blockers and pesticides before and after their exposure to UV light. The toxicological response of both Microtox ${ }^{\circledR}$ and Daphtoxkit $F^{\circledR}$ test, increased with the increase of the compound concentration. Triclosan water solution was considered as the most toxic. The lowest toxic effect was observed for Imidacloprid and Octyl-methoxycinnamate solutions. The exposure of Benzocaine, Octyl-methoxycinnamate and Triclosan water solutions to UV light led to an increase of their toxicity. An inverse relationship was observed for Imidacloprid and $17 \alpha$-Ethinylestradiol solutions.
\end{abstract}

\section{Introduction}

The natural environment, including primarily water ecosystems, shows a particular sensitivity to changes caused by anthropogenic activity. The development of industry, medical and personal care sectors as well as the agriculture and food processing sector cause a continuously increase in concentrations of a wide range of micropollutants in the aquatic environment [1]. Numerous research works indicated that several micropollutants, even in small concentrations of several $\mathrm{ng} / \mathrm{L}$, were characterized by a high toxicity to both living organisms [2-4] and human health [5]. Diversified impact of micropollutants on several indicator organisms makes it difficult to determine safe concentrations of those chemicals that do not cause adverse changes in the entire ecosystem. Hardly biodegradable compounds often require the use of advanced methods for their decomposition, which can enhance the water toxicity $[6,7]$.

The paper presents the assessment of the toxicological effect of different concentrations of organic micropollutants occurring in water solutions. The tested compounds belong to the group of industrial additives, pharmaceutical compounds, hormones, UV blockers and pesticides. In addition, the effect of UV irradiation on the increase in the toxicity of the prepared water solutions was evaluated. The toxicological tests were carried out using bioluminescent bacteria - Microtox ${ }^{\circledR}$ test and sweet water crustaceans - Daphtoxkit $\mathrm{F}^{\circledR}$.

\footnotetext{
* Corresponding author: edyta.kudlek@polsl.pl
} 


\section{Materials and methods}

\subsection{Micropollutant water solutions}

Water solution of selected organic micropollutants from the group of industrial additives (4-Nonylphenol), pharmaceutical compounds (Benzocaine and Imidacloprid), hormones (17 $\alpha$-Ethinylestradiol), UV blockers (Octyl-methoxycinnamate) and pesticides (Triclosan) constituted the subject of the study. The water solutions were prepared based on deionised water with the addition of patterns of the tested organic micropollutants with the concentration of $0.1,0.5,1.0,2.0$ and $5.0 \mathrm{mg} / \mathrm{L}$. All investigated organic micropollutants were purchased from Sigma Aldrich (Poland). Their characteristic was given in Table 1. Due to the poor water solubility of Octyl-methoxycinnamate and Triclosan, stock solutions of all micropollutants were prepared with methanol (analytical standard), Avantor Performance Materials Poland S.A. (Poland). The $\mathrm{pH}$ of the prepared water solutions was adjusted to 7 using $0.1 \mathrm{~mol} / \mathrm{L} \mathrm{HCl}$ or $0.1 \mathrm{~mol} / \mathrm{L} \mathrm{NaOH}$.

Table 1. The structural formula and chemical properties of the tested micropollutants.

\begin{tabular}{|c|c|c|}
\hline Structural formula & \multicolumn{2}{|c|}{ Chemical properties } \\
\hline \multicolumn{3}{|c|}{ 4-Nonylphenol (NP) } \\
\hline \multirow{4}{*}{$\mathrm{C}_{9} \mathrm{H}_{19}{ }^{\prime}$} & Compound group & Industrial additives \\
\hline & Molecular mass, g/mol & 220.35 \\
\hline & Solubility in water, $\mathrm{mg} / \mathrm{L}$ & 7.0 \\
\hline & $\log \mathrm{K}_{\mathrm{ow}}$ & 5.76 \\
\hline \multicolumn{3}{|c|}{ Benzocaine (BE) } \\
\hline \multirow[b]{4}{*}{$\mathrm{H}_{2} \mathrm{~N}^{-}$} & Compound group & Pharmaceuticals \\
\hline & Molecular mass, g/mol & 165.19 \\
\hline & Solubility in water, $\mathrm{mg} / \mathrm{L}$ & 1310 \\
\hline & $\log \mathrm{K}_{\text {ow }}$ & 1.86 \\
\hline \multicolumn{3}{|c|}{ Imidacloprid (IM) } \\
\hline & Compound group & Pharmaceuticals \\
\hline & Molecular mass, g/mol & 255.66 \\
\hline & Solubility in water, $\mathrm{mg} / \mathrm{L}$ & 0.61 \\
\hline & $\log \mathrm{K}_{\mathrm{ow}}$ & 0.57 \\
\hline \multicolumn{3}{|c|}{ 17a-Ethinylestradiol (EE2) } \\
\hline \multirow{4}{*}{$\mathrm{H}_{3} \mathrm{C} \stackrel{\mathrm{OH}}{\mathrm{N}} \equiv \mathrm{CH}$} & Compound group & Hormones \\
\hline & Molecular mass, g/mol & 296.40 \\
\hline & Solubility in water, $\mathrm{mg} / \mathrm{L}$ & 11.3 \\
\hline & $\log \mathrm{K}_{\mathrm{ow}}$ & 3.67 \\
\hline \multicolumn{3}{|c|}{ Octyl-methoxycinnamate (OMC) } \\
\hline & Compound group & UV blockers \\
\hline & Molecular mass, $\mathrm{g} / \mathrm{mol}$ & 290.40 \\
\hline & Solubility in water, $\mathrm{mg} / \mathrm{L}$ & 0.2 \\
\hline & $\log \mathrm{K}_{\text {ow }}$ & 6.1 \\
\hline \multicolumn{3}{|c|}{ Triclosan (TCS) } \\
\hline \multirow[b]{4}{*}{ 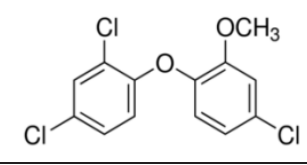 } & Compound group & Pesticides \\
\hline & Molecular mass, g/mol & 289.54 \\
\hline & Solubility in water, $\mathrm{mg} / \mathrm{L}$ & 0.1 \\
\hline & $\log \mathrm{K}_{\text {ow }}$ & 4.76 \\
\hline
\end{tabular}


Preliminary studies indicated no significant influence of the used alcohol, acid and alkali on the response of the used indicator organisms. The sensitivity of the Microtox ${ }^{\circledR}$ of the low concentration of methanol, hydrochloric acid nads hydroxide did not exeed $3 \%$.

The experiments for all tested compounds were carried out separately and in a mixture of the concentration of $1.0 \mathrm{mg} / \mathrm{L}$ of each micropollutant.

\subsection{UV irradiation process}

The process of UV light irradiation of the prepared micropollutant water solution was conducted in a glass reactor with a volume of $700 \mathrm{~mL}$. The used medium-pressure UV lamp (with a power of $150 \mathrm{~W}$ ) emitted radiation with wavelength $\lambda_{\text {exc }}$ equal to $313,365,405,436$, 546 and $578 \mathrm{~nm}$. The lamp was placed in the rector by the use of a glass jacket cooled by tap water. A magnetic stirrer was used to keep the water solutions in a constant move. The temperature of the water solution during the irradiation process did not exceed $20 \pm 1^{\circ} \mathrm{C}$.

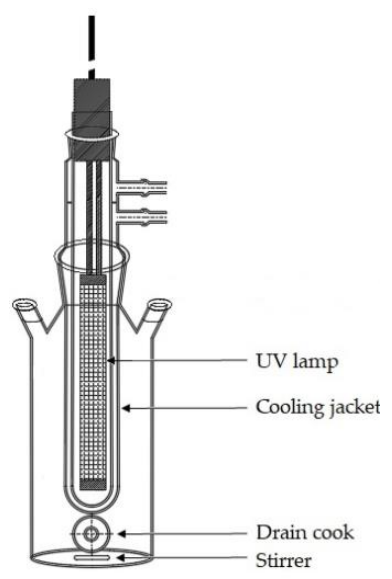

Fig. 1. Scheme of the reactor and the UV lamp [7].

\subsection{Toxicological assessment}

The toxicological assessment of the water solution before and after the irradiation with UV light was performed by the use of two biotest i.e. Microtox ${ }^{\circledR}$ test and Daphtoxkit $\mathrm{F}^{\circledR}$. The Microtox ${ }^{\circledR}$ bioassay bases on the measurement of the changes in the intensity of light emission by selected strains of bioluminescent bacteria Alivibrio fischeri. This bacteria are widely used bioindicators due to their high sensitivity for a broad range of toxicants including different groups of organic micropollutants. The test was conducted according to the Screening Test procedure, which allow for the estimation of the toxic effect of tested water samples comparative to a reference nontoxic sample after 5 and $15 \mathrm{~min}$ of exposure. The reference sample was a $2 \% \mathrm{NaCl}$ solution.

The test based on the Daphtoxkit $\mathrm{F}^{\circledR}$ by Tigret (Warszawa, Poland) were performed in conformity with the OECD Guideline 202 and ISO 6341. The test involves the observation of the indicator organisms reaction during exposureto the tested micropollutant water solutions.

Freshly hatched freshwater crustaceans Daphnia magna were use as test organisms. Observations of immobilization or mortality of crustaceans were carried out after 24 and $48 \mathrm{~h}$. The toxic effect $(E)$ was calculated according to the equation (1): 
where:

$$
E=\frac{\left(N_{c}-N_{t}\right)}{N_{c}} \cdot 100 \%
$$

$N_{c}$ - number of living indicator organisms in the control sample,

$N_{t}$ - number of living indicator organisms in the test sample.

The obtained test results of the toxicological effect of micropollutant water solutions allowed to classify them to particular toxicity classes listed in table 2 .

Table 2. Samples toxicity classification system [8]

\begin{tabular}{|c|c|}
\hline Effect, \% & Toxicity class \\
\hline$<25.0$ & Non toxic \\
\hline $25.0-50.0$ & Low toxic \\
\hline $50.1-75.0$ & Toxic \\
\hline $75.1-100$ & Highly toxic \\
\hline
\end{tabular}

\section{Results and discussion}

In the first stage of the study, the dependence of the micropollutants concentration in water solution on the increase of the toxic effect was assessed (Fig. 2). It has been demonstrated that the toxicity of water solutions increases with increasing concentration of the tested compound. For example, based on the results obtained from both bioassays water solutions containing NP at concentrations of 0.5 and $1.0 \mathrm{mg} / \mathrm{L}$ were classified (according to Table 2) as non toxic while water solutions of NP at concentrations of 1.0 and $2.0 \mathrm{mg} / \mathrm{L}$ were classified by the Microtox ${ }^{\circledR}$ test (conducted for $5 \mathrm{~min}$ ) and by the Daphtoxkit $\mathrm{F}^{\circledR}(24 \mathrm{~h}$ of exposure) as low toxic. Both toxicity test assigned samples containing $5.0 \mathrm{mg} \mathrm{NP} / \mathrm{L}$ as highly toxic (Fig. 2a).

The comparison of the test results from both the bioluminescent bacteria test and the freshwater crustaceans test showed differences in the sensitivity of the tests. This was particularly noticeable in the case of BE water solutions. Those solution more effective reacted with bacteria $\left(\right.$ Microtox $^{\circledR}$ test). The Microtox $^{\circledR}$ test was also more sensitive to sulutions containig IM, OMC and EE2 at the concetration of $5.0 \mathrm{mg} / \mathrm{L}$. Whereas crustaceans (Daphtoxkit $\mathrm{F}^{\circledR}$ ) were more sensitive to NP, TCS water solutions and samples containing $0.1,0.5$ and $1.0 \mathrm{mg} / \mathrm{L}$ of EE2.

Differences in registered toxic effects also depended on the duration of the test. This means that the exposure time of the indicator organism to the toxic substance caused these differences. For example, the Microtox ${ }^{\circledR}$ test conducted for $5 \mathrm{~min}$ gave a higher toxic response for NP, BE and IM solutions, than the same test conducted for $15 \mathrm{~min}$.

The highest toxic effect registered by both bioassays was observed for TCS. Its toxic nature has been proved in several studies conducted on water organisms and also on human cells [9]. The $\mathrm{EC}_{50}$ value of TCS calculated using the Microtox ${ }^{\circledR}$ test received $0.08 \mathrm{mg} / \mathrm{L}$. The negative impact of low concentration of TCS on living organisms resulted from its antibacterial properities, which contributed to a widespread use of this compound in several personal care products $[10,11]$. Thus, the concentration of this compound detected in European and American rivers ranged from 0.0006 to $2.3 \mu \mathrm{g} / \mathrm{L}$ [12].

Water samples with a concentration of 2.0 and $5.0 \mathrm{mg} / \mathrm{L}$ of EE2 were classified, regardless of the used test, as toxic. However solutions containing 0.5 or $1.0 \mathrm{mg} / \mathrm{L}$ of this hormone compound were considered to be low toxic. The solution of BE in the concentration of 2.0 and $5.0 \mathrm{mg} / \mathrm{L}$ and the $1.0 \mathrm{mg} / \mathrm{L} \mathrm{NP}$ concentration were also classified as low toxic. 
The lowest toxic effect was observed for IM and OMC. Water samples containing IM or $\mathrm{OMC}$ in concentration up to $1.0 \mathrm{mg} / \mathrm{L}$ were classified as non toxic. In the case of 2.0 and $5 \mathrm{mg} / \mathrm{L} \mathrm{IM}$ water solution only the Microtox ${ }^{\circledR}$ bioassay showed a low toxicity to bacteria after $5 \mathrm{~min}$ of exposure. Nevertheless test conducted on water organisms and soil invertebrates indicated a high toxicity of this pharmaceutical compound [13].

(a)

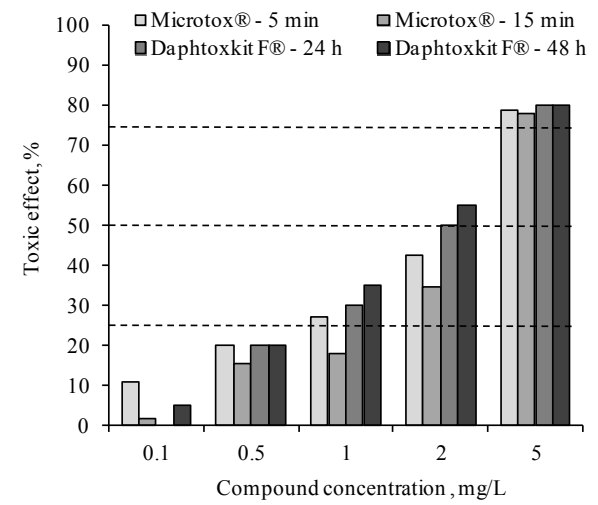

(c)

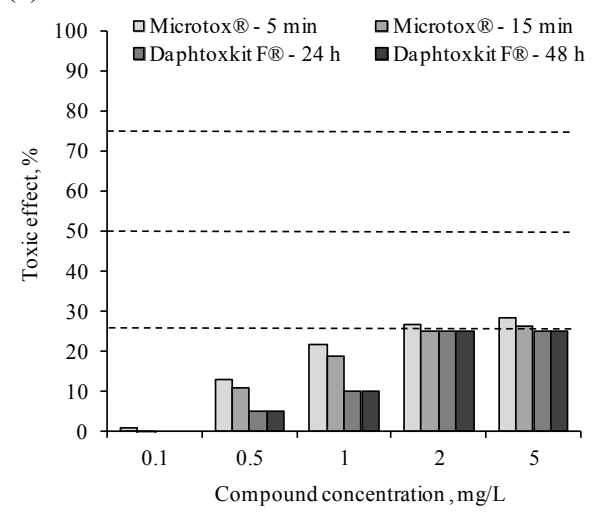

(e)

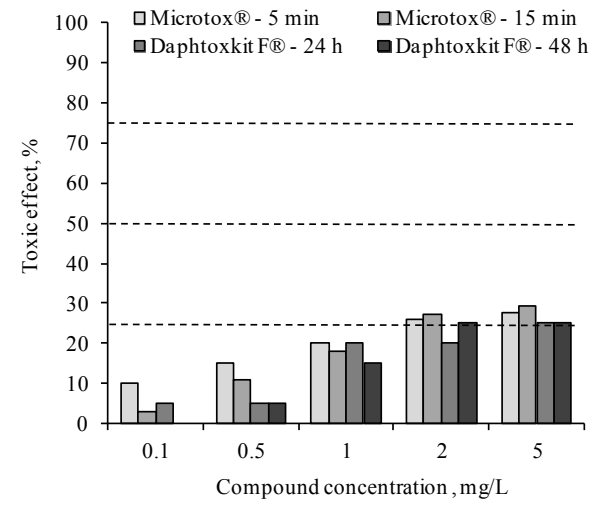

(b)

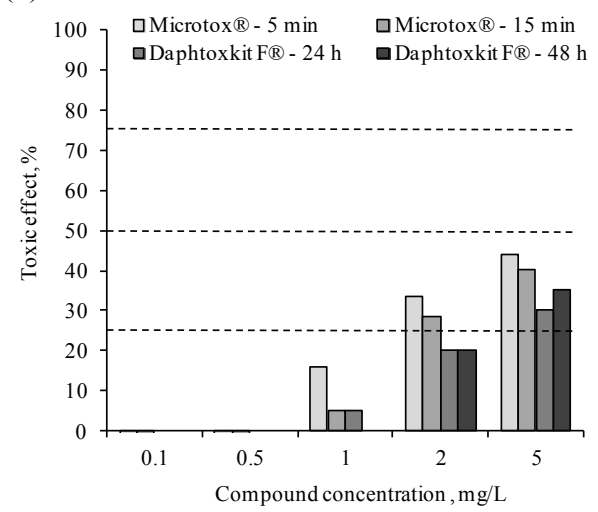

(d)

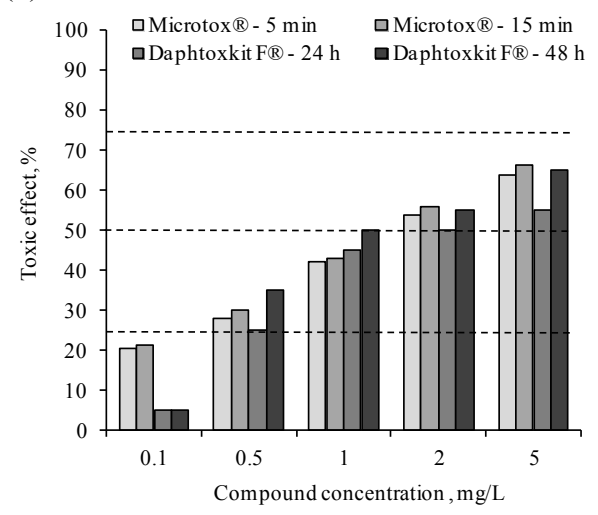

(f)

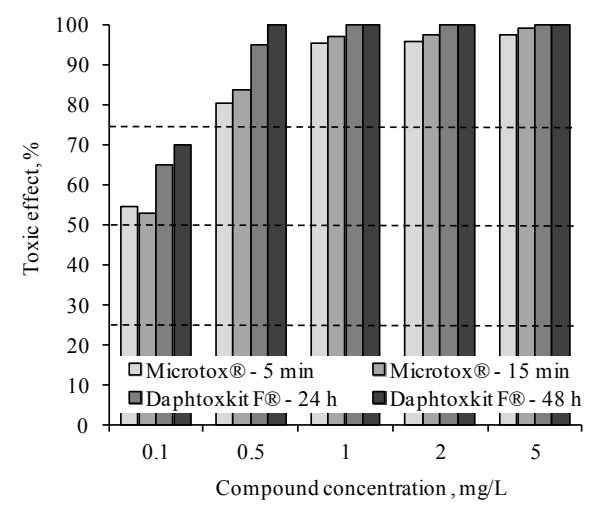

Fig. 2. Comparison of the toxic effect obtained by both toxicity tests for different concentrations of (a) NP, (b) BE, (c) IM, (d) EE2, (e) OMC and (f) TCS. 
Real water streams contain many different micropollutants, therefore the toxicity of the mixture of the tested organic micropollutants was also examined. Based on the toxic effect of the solution containing only one compound, especially TCS, it can be assumed that the compound mixture has also a high toxic nature at all concentrations. However, the obtained toxicological results for both bioassays indicated a lower toxicity against TCS water solutions. The toxic effect of the mixture with different concentration was shown in Figure 3.

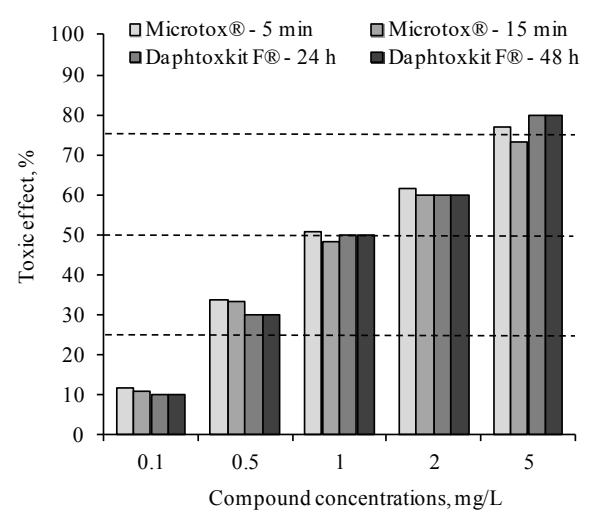

Fig. 3. Dependency of the concentration of micropollutant mixture on the toxic effect.

The water solution with the lowest concentration $(0.1 \mathrm{mg} / \mathrm{L}$ of each micropollutant $)$ did not show a toxic effects on indicator organisms, while the micropollutant water solutions witha concentration of 0.5 and $1.0 \mathrm{mg} / \mathrm{L}$ were classified by both toxicity tests as low toxic. Only the Microtox ${ }^{\circledR}$ test conducted for 5 min sugests a toxic nature of the $1.0 \mathrm{mg} / \mathrm{L}$ micropollutant solution. The toxicity of the micropollutant water mixture increased with the compound concentration, so the water samples with $5.0 \mathrm{mg} / \mathrm{L}$ of each micropollutant were classified as high toxic.

All prepared micropollutant water solutions were subjected to UV irradiation for 5, 15 , 30 and $60 \mathrm{~min}$. UV light can lead to the decomposition of micropollutants and the formation of several decomposition by-product [14]. Those product can raise the toxic nature of micropollutant water solutions [7]. The results obtained during the Microtox ${ }^{\circledR}$ test (5 min of expousure) for water mixture containing all micropollutants with the concentration of $1 \mathrm{mg} / \mathrm{L}$ (of each component) are presented in Figure 4.

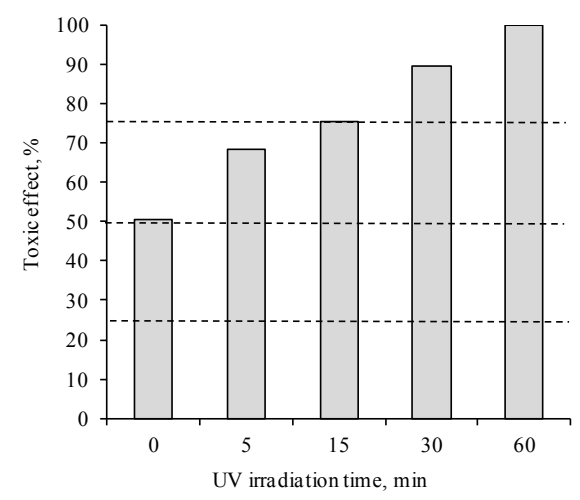

Fig. 4. Influence of the UV irradiation time on the toxic effect of the water mixture of micropollutants (each compound concentration: $1 \mathrm{mg} / \mathrm{L}$; test: Microtox $^{\circledR}-5 \mathrm{~min}$ of exposure). 
The toxic effect increased with the increasing UV irradiation of the water solution. After 5 min of irradiation the tested water was toxic and after $15 \mathrm{~min}$ it could be defined as highly toxic. The solution containing only one organic micropollutant was characterized by a lower toxicity than the mixture of all compounds (Fig. 5). Only the water solution of TCS was high toxic after only the first 5 min of UV irradiation. The higher toxicity of the water solution of all micropollutants after UV irradiation indicated an interaction between the formed decomposition products and the formation of toxic by-products.

(a)

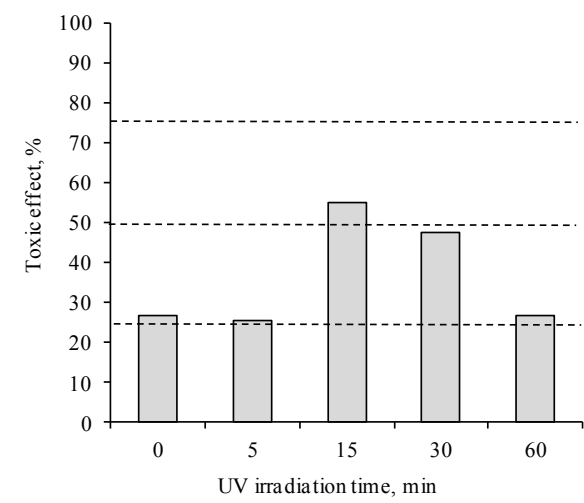

(c)

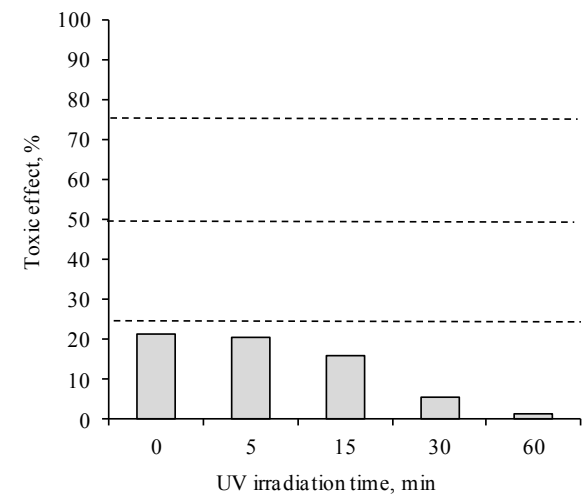

(e)

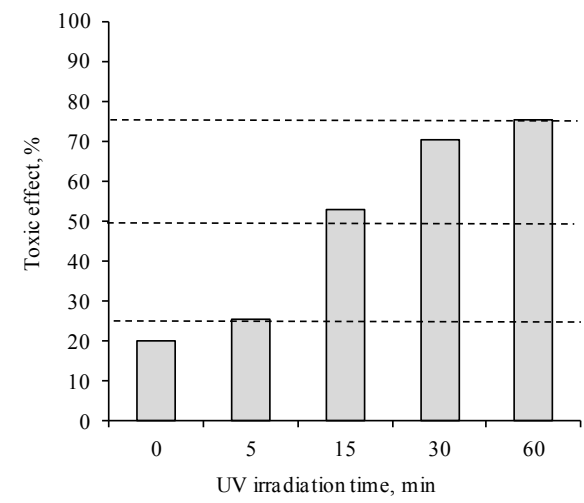

(b)

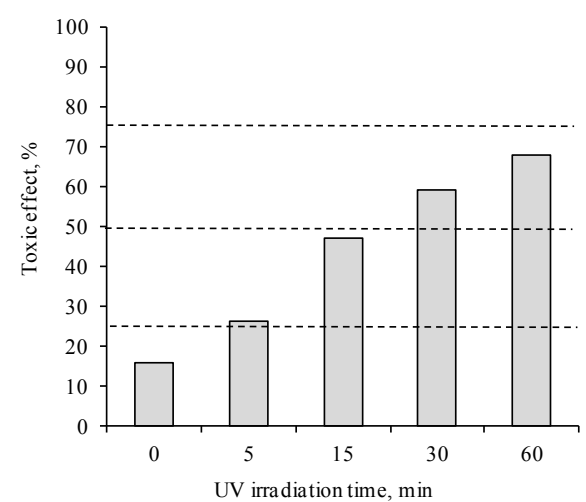

(d)

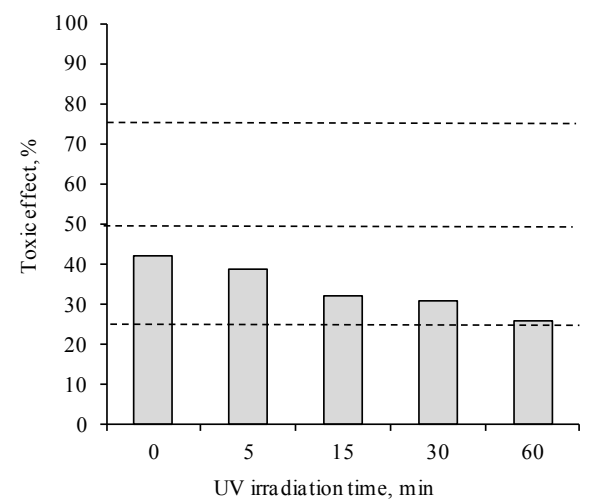

(f)

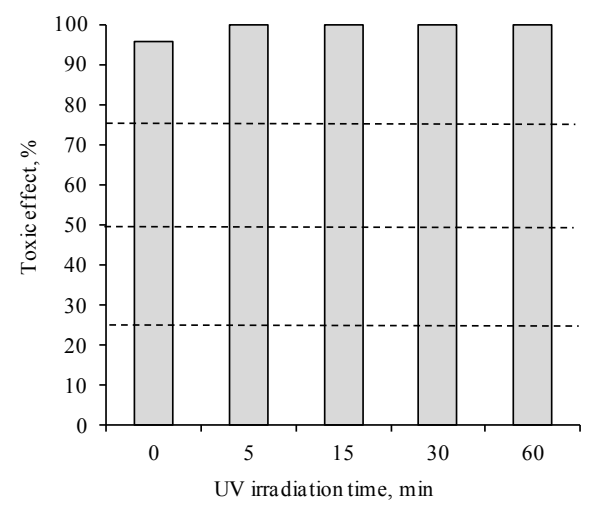

Fig. 5. Influence of the UV irradiation time on the toxic effect of water samples containing $1 \mathrm{mg} / \mathrm{L}$ of (a) NP, (b) BE, (c) IM, (d) EE2, (e) OMC and (f) TCS. 
The irradiation of the non toxic $\mathrm{BE}$ and $\mathrm{OMC}$ water solutions resulted in the increase of their toxicity. The solutions of this compounds after $60 \mathrm{~min}$ of exposure to UV light were classified as toxic. An inverse dependence was observed during the irradiation of the IM and EE2 solutions. The toxic effect of these solutions were reduced with the increasing irradiation time. An interesting relationship was observed for the NP water solution. The first $15 \mathrm{~min}$ of exposure to UV light led to the increase of the water toxicity to the level of toxic solutions. The further irradiation resulted in a decrease of the toxicity of the solution to a low toxic level. Therefore it is considered that organic micropollutants were subject in the natural environment to numerous reactions, which can change their impact on different organisms.

\section{Conclusions}

On the basis of the conducted investigations it can be observed that the organic micropollutants form various groups can affect on water organisms differently. The toxicological response of both Microtox $^{\circledR}$ and Daphtoxkit $F^{\circledR}$ test increased with the increase of the compound concentration. The comparison of test results from both tests showed differences in the sensitivity of the bioassays. The Microtox ${ }^{\circledR}$ test was more sensitive to sulutions containig BE, IM and OMC, while Daphtoxkit $\mathrm{F}^{\circledR}$ showed a higher toxic effect for NP, EE2 and TCS solutions. TCS water solution were considered as the most toxic. The lowest toxic effect was observed for IM and OMC solutions. The exposure of BE, OMC and TCS water solutions to UV light led to an increase of their toxicity. An inverse relationship was observed for IM and EE2 solutions. An increase of the toxicity with the UV irradiation time was also observed for the water mixtures of all tested micropollutants. Samples collected after $30 \mathrm{~min}$ of irradiation were classified as high toxic. It can be assumed that during the UV decomposition of the tested compounds, several toxic by-products, which increase the toxicity of the water solution, were formed.

This work was supported by Ministry of Science and Higher Education Republic of Poland within statutory funds.

\section{References}

1. M.-K. Kim, K.-D. Zoh, Environ. Eng. Res. 21, 319 (2016)

2. A. Pal, K.Y. Gin, A.Y. Lin, M.Reinhard, Sci. Total. Environ. 408, 6062 (2010)

3. J.M. Brausch, K.A. Connors, B.W. Brooks, G.M. Rand, Rev. Environ. Contam. Toxicol. 218, 1 (2012)

4. H.I. Fekete-Kertész, Z. Kunglné-Nagy, K. Gruiz, Á. Magyar, É. Farkas, M. Molnár, Period. Polytech. Chem. Eng. 59, 262 (2015)

5. C.J. Houtman, J. Kroesbergen, K. Lekkerkerker-Teunissen, J.P. van der Hoek, Sci. Total Environ. 496, 54 (2014)

6. J. Richard, A. Boergers, C. Vom Eyser, K. Bester, J. Tuerk, Int. J. Hyg. Environ. Health. 217, 506 (2014)

7. E. Kudlek, Proceedings. 2, 1 (2018)

8. J. Bohdziewicz, E. Kudlek, M. Dudziak, Desalin. Water Treat. 57, 1552 (2016)

9. C. Ajao, M.A. Andersson, V.V. Teplova, S. Nagy, C.G. Gahmberg, L.C. Andersson, M. Hautaniemi, B. Kakasi, M. Roivainen, M. Salkinoja-Salonen, Toxicol. Rep. 2, $624(2015)$ 
10. A.C. Asimakopoulos, N.S. Thomaidis, K. Kanna, Sci. Total Environ. 470-471, 1243 (2014)

11. R.U. Halden, Environ. Sci. Technol. 48, 3603 (2014)

12. A.B. Dann, A. Hontela, J. Appl. Toxicol. 31, 285 (2011)

13. C. de Lima e Silva, N. Brennan, J.M. Brouwer, D. Commandeur, R. A. Verweij, C.A.M. van Gestel, Ecotoxicology 26, 555 (2017)

14. E. Kudlek, M. Dudziak, J. Bohdziewicz, Water 8, 1 (2016) 